\title{
ON GILGAMESH AND HOMER: ISHTAR, APHRODITE AND THE MEANING OF A PARALLEL*
}

\begin{abstract}
'A reading of the Gilgamesh Epic, even a casual reading, seems naturally to suggest comparison with the Homeric epos.' So G.K. Gresseth in 1975, when he could already situate his work in a long tradition of comparative studies. ${ }^{1}$ Many scholars would subscribe to this impression, which evokes an aesthetic experience portrayed as necessary and inevitable ('naturally'). Yet they would also agree that establishing how archaic Greek literature relates to the ancient Near Eastern context is no straightforward exercise. ${ }^{2}$ One of the most contested questions concerns the possibility of Homer's drawing on preserved Near Eastern works, for there is no agreement on when a parallel can be taken as indicating reception. ${ }^{3}$ The
\end{abstract}

* A Henri Frankfort Fellowship at the Warburg Institute in Winter Term 2019 enabled me to complete this article. I am also grateful to H. Albery, A. Cavigneaux, E. Cingano, M. Hose, I.J.F. de Jong, E. Jiménez, A. Johnston, A. Kelly, C. Metcalf, F. Reynolds, E. Roßberger and H. Spelman for written comments, and to audiences at the 2016 Venice Advanced Seminar in the Humanities, the $64^{\text {th }}$ Rencontre Assyriologique Internationale in Innsbruck, and in Oxford, Munich and London.

${ }^{1}$ G.K. Gresseth, 'The Gilgamesh epic and Homer', CJ 70 (1975), 1-18, at 1. For earlier comparisons see W. Burkert, 'Homerstudien und Orient', in J. Latacz (ed.), Zweihundert Jahre Homer-Forschung (Stuttgart, 1991), 155-81 = id., Kleine Schriften I. Homerica (Göttingen, 2001), $30-58$.

The following works are cited by author's name and year: M. Bachvarova, From Hittite to Homer. The Anatolian Background of Ancient Greek Epic (Cambridge, 2016); W. Burkert, The Orientalizing Revolution. Near Eastern Influence on Greek Culture in the Early Archaic Age (Cambridge MA, 1992); B. Currie, Homer's Allusive Art (Oxford, 2016); M.L. West, The East Face of Helicon. West-Asiatic Elements in Greek Poetry and Myth (Oxford, 1997).

${ }^{2}$ The landmarks are Burkert (1992), id., Kleine Schriften II: Orientalia (Göttingen, 2002), and West (1997). The current state of research will be largely exemplified in A. Kelly and C. Metcalf (edd.), Gods and Mortals in Early Greek and Near Eastern Mythology (Cambridge, forthcoming); see C. López-Ruiz, 'Greek and Near Eastern mythologies: a story of Mediterranean encounters', in L. Edmunds (ed.), Approaches to Greek Myth (Baltimore, 2014), 154-99, and the following footnote.

${ }^{3}$ Burkert (1992), 88-114 (especially 95) envisaged the Iliad poet drawing on written versions of the Akkadian Gilgamesh; West (1997), 334-47, 400-2, and passim 347-437, saw a pervasive influence of Gilgamesh on Homer, though this is an exception to his model of diffusion, which does not generally envisage a direct link with specific Near Eastern sources. Recently in favour of conscious reception (through lost intermediaries) and artful redeployment: R. Rollinger, 'Old battles, new horizons: the ancient Near East and the Homeric epics', in id. and E. van Dongen (edd.), Mesopotamia in the Ancient World (Münster, 2015), 5-32, Currie (2016), 147-222 (oral or written transmission), A. Lardinois, 'Eastern myths for Western lies: allusion to Near Eastern mythology in Homer's Iliad', Mnemosyne 71 (2018), 895-919 (oral intermediaries), M. Clarke, Achilles Beside Gilgamesh. Mortality and Wisdom in Early Epic (Cambridge, 2019) (oral or written, with a finegrained distinction of levels of intertextuality at 24-34). Bachvarova (2016) argues that SyroAnatolian traditions had a major impact on Homeric epic via bilingual bards, not least in conveying Mesopotamian literature; this model allows for the recognisable reception of surviving Babylonian narratives, including Gilgamesh. In favour of a contextualising approach which deemphasizes direct reception is A. Kelly, 'The Babylonian captivity of Homer: the case of the $\Delta$ iò $ৎ$ 'A $\pi$ ó $\tau \eta$ ', RhM 151 (2008), 259-304, id. 'Homeric battle narrative and the ancient Near East', in D. Cairns and R. Scodel (edd.), Defining Greek Narrative (Edinburgh, 2014), 29-54. C. Metcalf, The Gods Rich in Praise. Early Greek and Mesopotamian Religious Poetry (Oxford, 2015) promotes a diachronic perspective and strict historical criteria for identifying influence, with mostly negative results. Also sceptical of 
controversies surrounding intertextual readings of early Greek epic persist, since the uncertainty as to how far Homeric poetics worked through textual allusion and borrowing is bound up with debates about the poems' fixity as texts, as well as their mechanisms, date and media of composition. ${ }^{4}$ Questions multiply when the intertextual approach is transferred to a highly fragmented cross-cultural stage spanning millennia as well as several languages and literary cultures. ${ }^{5}$

Since W. Burkert's assessment, the 'plaint-in-heaven' scenes involving Ishtar (SB Gilgamesh VI 80-124) and Aphrodite (Homer, Iliad 5.367-420) have been ranked among the most conspicuous instances of a Babylonian poem's influence on Homer. ${ }^{6}$ The present article seeks to situate this important parallel in a wider context. A case will be made that Homer's Aphrodite scene is unlikely to represent an interaction with the Gilgamesh Epic. It is further argued (not as a necessary consequence of this sceptical stance) that the two episodes are best seen as part of a broader constellation of scenes which speak for cross-culturally shared poetic means and conceptions. Recognising this sharing as a function of poetic performance supports the hypothesis of a long-term process of oral contact and communication preceding the shaping of the Homeric epics. Oral transmission to Greece has long been proposed, but remains to be supported by comparative assessments of compositional features relating to orality and performance. ${ }^{7}$

Homer's use of Gilgamesh is R. Rutherford, Homer. Iliad Book XVIII (Cambridge, 2019), 231-6. The Akkadian epic's editor and commentator does not envisage a historical connection with the Homeric poems, cf. A.R. George, The Babylonian Gilgamesh Epic. Introduction, Critical Edition, and Cuneiform Texts (Oxford, 2003, 2 vols.), 54-7. Fruitful comparisons need not concentrate on literary transmission; cf. J. Haubold, Greece and Mesopotamia. Dialogues in Literature (Cambridge, 2013), 1-72.

${ }^{4}$ On this debate see M. Finkelberg, 'Homer and his peers. Neoanalysis, oral theory, and the status of Homer', TiC 3 (2011), 197-208 = ead., Homer and Early Greek Epic. Collected Essays (Berlin, 2020), 158-68; F. Montanari, A. Rengakos and C. Tsagalis (edd.), Homeric Contexts. Neoanalysis and The Interpretation of Oral Poetry (Berlin, 2012); Currie (2016), 1-38.

${ }^{5}$ A good guide is C.S. Ehrlich (ed.), From an Antique Land. An Introduction to Ancient Near Eastern Literature (Lanham, 2009). We have lost the Iron Age Levantine and Anatolian narratives which the Greeks are likely to have encountered in the crucial formative period of Hellenic epic, before and after borrowing the alphabet. On the Phoenician (and generally West-Semitic) tradition as the closest to the Greek see C. López-Ruiz, When The Gods Were Born. Greek Cosmogonies and The Near East (Cambridge MA, 2010), envisaging oral diffusion within a cultural koinē.

${ }^{6} \mathrm{~W}$. Burkert, 'Götterspiele und Götterburleske in altorientalischen und griechischen Mythen', Eranos Jahrbuch 51 (1982), 335-67, at 356-8 $\approx$ id., Die orientalisierende Epoche in der griechischen Religion und Literatur (Heidelberg, 1984), 92-5 $\approx$ id. (1992), 96-9 $\approx$ id., Babylon, Memphis, Persepolis. Eastern Contexts of Greek Culture (Cambridge, MA, 2004), 40-4, building on Gresseth (n. 1), 14-15 n. 24. See also C. Penglase, Greek Myths and Mesopotamia (London, 1994), 3, Ø. Andersen, 'Diomedes, Aphrodite, and Dione: background and function of a scene in Homer's Iliad', C\&M 48 (1997), 25-36, West (1997), 362, B. Breitenberger, Aphrodite and Eros (London, 2007), 16-20, A.C. Cassio, 'Kypris, Kythereia, and the fifth book of the Iliad', in Montanari, Rengakos and Tsagalis (n. 4), 413-26, at 420-1, B. Currie, 'The Iliad, Gilgamesh, and Neoanalysis', ibid., 543-80, at 563, id. (2016), 173-8 and 193-8 (the most detailed discussion after Burkert), E. Allen-Hornblower, 'Gods in pain: walking the line between divine and mortal in Iliad 5', Lexis 32 (2014), 27-58, at 35 n. 45, Bachvarova (2016), 325-7, and Clarke (n. 3), 193-5, 3301 .

${ }^{7}$ See above n. 3; cf. R. Mondi, 'Greek mythic thought in the light of the Near East', in L. Edmunds (ed.), Approaches to Greek Myth (London, 1990), 142-98, at 150, West (1997), 590-610, 
An initial one-on-one comparison will soon lead us to consider further divine complaints and requests to Zeus in the Iliad $(\S 1)$ and other early hexameter poems $(\S 2),{ }^{8}$ and then to frame the Iliad scene within the poem's divine narrative ( $\left.\$ 3\right)$. The second part of the article moves on to the Near Eastern context of the Gilgamesh episode: scenes of reviled or upset deities complaining and making requests to chief gods are widespread in the Near East as in Greece-more widespread, in fact, than hitherto recognized. After drawing a comparison with occurrences in SumeroAkkadian, Ugaritic and Hurro-Hittite poetry (\$4), we will examine relevant aspects of literary diffusion across the Near East, and towards Greece ( $\$ 5)$.

\section{A COMPLEX COMPARISON}

Let us begin with a summary and with Burkert's assessment of the similarities, which has remained the basis of the current consensus. We will then consider the presence of comparable scenes in the Iliad.

Prompted by Athena, Diomedes wounds and scorns Aphrodite (Homer, Il. 5.330-51). Helped by Iris and Ares, she flies to Olympus and falls to the knees of her mother Dione (352-70), who consoles Aphrodite by listing past cases of deities suffering pains at the hands of mortals, and recognizes Athena's intervention (371415). As Aphrodite's wound is cured, Athena, sitting beside Hera, mocks Aphrodite. A detached Zeus smiles, and tells Aphrodite that she is not quite fit for deeds of warfare, her province being the deeds of marriage (416-30). In SB Gilgamesh VI, Ishtar sets her eyes on Gilgamesh, who has just triumphed over the monstrous Humbaba, and propositions him promising riches and power (SB Gilg. VI 1-21). The king refuses, listing the evils she has caused to her previous lovers (22-79). The goddess ascends in tears to Heaven, where she finds her father and mother, Anu and Antu (80-3). Heedless and vindictive, Ishtar successfully requests the Bull of Heaven to slay Gilgamesh and wreak havoc on his city Uruk, in spite of Anu's hesitation (84-114).

'The two scenes parallel each other in structure, narrative form and ethos to an astonishing degree'-so Burkert. ${ }^{9}$ The goddess, offended by a hero, goes up to heaven in distress and talks to her father, who does not seem particularly sympathetic. Each scene presents a 'catalogue' of past events. ${ }^{10}$ Besides Aphrodite being a love-goddess just as Ishtar is, each pair of parents share the same name, Dione being a feminine derivative of the name Zeus, just as in Akkadian Antu is the feminine of Anu. Crucially, Dione appears only here in the Iliad, and no mother is envisaged in Hesiod's account of Aphrodite's birth (Hesiod, Theog. 188-200).

W.F.M. Henkelman, "'The Birth of Gilgameš" (Ael. NA XII.21): a case-study in literary receptivity', in R. Rollinger and B. Truschnegg (edd.), Altertum und Mittelmeerraum. Die antike Welt diesseits und jenseits der Levante (Stuttgart, 2006), 807-56; I. Rutherford, 'Hesiod and the literary traditions of the Near East', in F. Montanari, A. Rengakos and C. Tsagalis (edd.), Brill's Companion to Hesiod (Leiden, 2009), 9-35, at 33, López-Ruiz (nn. 2 and 5).

${ }^{8}$ This move reflects methodological concerns expressed in Kelly (n. 3).

${ }^{9}$ Burkert (1992), 97.

${ }^{10}$ See below n. 36 
Burkert concludes that 'Homer proves to be dependent on Gilgamesh even at the linguistic level, forming the name of Dione as a calque on Antu.'11

Later scholarship has amply undermined the claim of a parallel structure and ethos. First, Antu plays quite a marginal part in the preserved Babylonian episode, being a mere appendage to Anu in SB Gilg. VI 83, whereas Dione is the main character of the Greek scene. ${ }^{12}$ We may add that Antu is absent in the only Akkadian surviving forerunner to the SB version's ascent (George's Bog $\breve{g}_{2}$ ). ${ }^{13}$ Second, contrary to Ishtar, Aphrodite is 'decidedly non-polemic' and gentle; she asks nothing of Zeus nor of anyone. ${ }^{14}$ Third, whereas the Babylonian scene consists of Anu and Ishtar having a long debate, Zeus appears briefly, albeit crucially, at the end of the episode only. Anu opposes Ishtar's request and then yields to her threat; Aphrodite does not address Zeus, who rebukes her mildly, if at all. In fact, the structure is quite different, and so is the characters' ethos. ${ }^{15}$

Still, it may be thought that differences are only to be expected in a thoughtful adaptation of an Akkadian model. ${ }^{16}$ Degrees of subjectivity in evaluating how 'striking' a parallel is are inevitable, but much depends on one's position regarding the traditional status of Homer's techniques. The compositional background to the scene becomes decisive.

The Iliad presents several parallel scenes. One can be found in Dione's catalogue, with Hades wounded by Heracles and cured in Olympus (Il. 5.398402). ${ }^{17}$ Burkert refers to one further occurrence at 21.505-14, where Artemis, maltreated by Hera, ascends to Olympus and laments to her father. A third example involves Ares: just like Aphrodite, Ares too has been wounded by Diomedes and goes up to Olympus; unlike Aphrodite, but like Artemis, he complains to Zeus (5.868-906). On the level of structure and ethos, the Artemis and Ares scenes are closer to Ishtar's ascent than the Aphrodite one. Both deities, like Ishtar, address their father; and Ishtar's behaviour, if anything, resembles that of Ares, for both of them complain forcefully and have a long exchange with a father who reacts (at least initially) negatively and offers no kind word.

We seemingly face two options. Homer may have devised the three scenes in imitation of the Gilgamesh episode, connecting them meaningfully both to one another and to his Babylonian source. Alternatively, this is a pre-existing pattern which Homer inherited from the Greek tradition and used for his own purposes; if this is the case, the hypothesis of a Babylonian model becomes unnecessary.

Oralists are likely to go for the second option. Fenik has shown that the narrative blocks constituting the two battle portions of Iliad Book 5 which culminate with Diomedes' encounters with Aphrodite and Ares are largely parallel, and repeated elsewhere in the poem. ${ }^{18}$ This he takes as evidence of traditional techniques and as

\footnotetext{
${ }^{11}$ Burkert (1992), 98.

${ }^{12}$ Cassio (n. 5), 420.

${ }^{13}$ George (n. 3), 317-25 (VAT 12890).

${ }^{14}$ Andersen (n. 5), 35.

${ }^{15}$ Ibid., 36: 'tremendous difference in ethos'; cf. Allen-Hornblower (n. 5), 42-5.

${ }^{16}$ Andersen (n. 5), 35-6, Currie (2016), 174-8.

17 Athetized by West after Koechly without manuscript justification. K. Sekita, 'Hades and Heracles at Pylos: Dione's tale dismantled', $C Q 68$ (2018), 1-9, defends the text at 2-3 n. 7.

${ }^{18}$ B. Fenik, Typical Battle Scenes in the Iliad, (Wiesbaden, 1968), 40-5.
} 
a warning against inferring intra-textual connections based on such similarities. The correspondences between the three divine scenes mean that 'the poet(s) had a basic pattern in mind which could be expanded or shortened as the occasion or the poet's own mood required.' 19

But the alternative view is not to be dismissed lightly. Currie argues, I think correctly, that these divine scenes are consciously associated in the poet's design. They belong to a wider web of structural correspondences between Books 4-5 and 20-21, extending beyond matters of technique and including Ares' cross-reference to his wound (Il. 21.396-9). ${ }^{20}$ If these are not type-scenes, they can be connected, and if they are connected, they can be meaningfully shown to deploy Gilgamesh.

Fenik and Currie are both aware that composition by type-scene and meaningful connections reflecting authorial designs are not mutually exclusive. ${ }^{21}$ It is certainly reasonable to state that Homer connects the three divine scenes at the same time as he deploys a traditional technique. Because the traditional background does not in itself preclude a Babylonian re-use and adaptation within traditional Greek parameters, the hypothesis of a cross-cultural reception should then rely on how compelling the case for a meaningful deployment of the adduced source across the three Iliad scenes turns out to be.

Burkert draws a distinction between Aphrodite's ascent and Artemis', and attaches no particular artistic meaningfulness to the alleged Babylonian redeployment. ${ }^{22}$ More recently, it has been maintained that Ishtar (goddess of love and war) becomes split between Homer's love and war deities, ${ }^{23}$ Artemis being fitting too because of Ishtar's associations with hunting. ${ }^{24}$ One could easily argue, however, that Aphrodite, Ares and Artemis were well known to Greek audiences, and that it is easier to imagine that all of them being hurt would be related to their status as pro-Trojan deities. ${ }^{25} \mathrm{We}$ are therefore bound to return to the strength of the parallel.

We have seen that Ishtar parallels Ares much more than Aphrodite, that Dione can hardly be compared with Antu's exiguous function, and that Anu's exchange with the raging Ishtar has little to do with the smiling Zeus's remark to a meek Aphrodite. We are left with the identity of the characters, and with a narrative structure which runs as follows: slandered deity ascends to heaven in distress and talks to a not particularly sympathetic chief god. Before assessing the characters' identity, it is worth exploring further the common narrative structure, looking at how the corpus of early Greek hexameter as a whole can contribute to the discussion.

\footnotetext{
${ }^{19}$ Fenik (n. 18), 175. Compare the criticism of Burkert's view by Mondi (n. 7), 190 n. 7, who considers the ascents of Aphrodite, Ares and Artemis a 'scene type'.

${ }^{20}$ Currie (2016), 196-7, adding H. Erbse, 'Betrachtungen über das 5. Buch der Ilias', RhM 104 (1961), 156-89, at 160 and 184-5.

${ }^{21}$ Fenik (n. 18), 43, Currie (2016), 197: 'there are strong grounds for regarding this as a specific intratextual allusion, not (just) a type-scene.'

22 Burkert (1992), 97-9; on this type of 'argument by isolation' see Kelly (n. 3, 2008).

${ }^{23}$ Bachvarova (2016), 326, Currie (2016), 197.

${ }^{24}$ Currie (2016), 197-8.

${ }^{25}$ On these scenes and Homer's divine narrative see below $\S 3$.
} 


\section{THE BROADER GREEK PICTURE}

Andersen holds that Artemis' ascent 'is probably not another instance of a typical scene (" god complaining in heaven'), but a repetition with variations of a typically Iliadic scene.' 26 This formulation leaves room for the Gilgamesh connection, provided we first accept that three (indeed, four, counting Hades' ascent) does not make the typical; ${ }^{27}$ and second, most important, that the Babylonian parallel is shown to be closer to the Iliadic scenes than to a typically Greek background as can be reconstructed. ${ }^{28}$

The three Homeric scenes are much closer to one another than to the Babylonian one in at least two crucial aspects: first, the three pro-Trojan deities are physically harmed; second, though Aphrodite, Ares and Artemis denounce their opponents, none of them has a request for Zeus, makes things particularly difficult for him, or threatens him. While Zeus smiles benignly to his daughters and lets Ares be cured, he does not concede anything. This is significant because what happens in SB Gilgamesh VI in this respect is much closer to what we repeatedly see elsewhere in early Greek hexameter poetry, where it is undoubtedly typical for a reviled or concerned deity to approach Zeus with some complaint and/or request. Matters are often more serious for the chief god than in our three Iliadic scenes, just as they are in Gilgamesh:

(1) Il. 1.493-530: Thetis ascends to Olympus and requires Zeus's help on account of Achilles.

(2) Il. 5.753-67: Hera and Athena approach Zeus, Hera complains about Ares.

(3) Il. 7.443-61: Poseidon, in the divine assembly, complains about the Achaean wall, whose construction diminishes his $k \lambda \varepsilon$ és.

(4) Il. 9.510-12: the Litai go to their father Zeus when a man rejects them and ask him to send Ate to that man.

(5) Od. 1.44-102: Athena, in the divine assembly, laments Odysseus' fate and invites Zeus to take action.

(6) $\mathrm{Od}$. 5.5-43: Athena, in the divine assembly, impatiently 'lists the many sorrows' of Odysseus.

(7) Od. 12.374-90: Lampetie ascends to Olympus to alert Helios, who complains to Zeus about his cattle, impiously devoured by Odysseus' shipmates.

(8) Od. 13.125-60: Poseidon complains to Zeus about the Phaeacians, whose escort risks leaving him dishonoured among the gods.

(9) Od. 20.73-6: Aphrodite asks Zeus to concede marriage to Pandareus' daughters.

(10) Hes. Op. 258-62: As soon as one of the kings reviles Dike with crooked slander, she reports to Zeus, who makes the $\delta \tilde{n} \mu \circ$ s pay for the kings' injustices.

(11) Hymn. Aphr. 220-3: Eos asks Zeus to bestow immortality on Tithonus.

\footnotetext{
${ }^{26}$ Andersen (n. 5), 32; cf. Currie (2016), 197 n. 269.

27 'Two as typical': Fenik (n. 18), 5, J.L. Ready, The Homeric Simile in Comparative Perspectives (Oxford, 2018), 208.

${ }^{28}$ Currie (2016), 200 appears to share this methodological point.
} 
There is, admittedly, much variety here. Cases in paradigmatic contexts ([4], [9], [10], [11], cf. Il. 5.398-402) are tightly executed, with no conversation. Zeus's dialogues with Athena in the Odyssey, and Poseidon's complaints ([3], [8]), are not preceded by a journey. We should probably not strive to explain them as exceptions. ${ }^{29}$ Some mechanisms in these scenes will be examined more closely in conjunction with Near Eastern texts: there too deities can lament and make requests to chief gods without necessarily travelling. Equally, they often complain about themselves, but sometimes their requests concern a mortal protégé (Thetis, Athena, Aphrodite, Eos), or another deity.

This is not a 'type-scene' in the sense of 'an oft-repeated block of words and phrases arranged in a characteristic sequence that describes a commonly occurring activity. ${ }^{30}$ These scenes can scarcely be used interchangeably with minor adaptations, and it would possibly be misleading to say that they all derive from inherited mental templates. ${ }^{31}$ Nevertheless, they decidedly indicate that the Iliad and Odyssey poets were not themselves responsible for introducing 'upset divine complaint/request' scenes into the Greek epic repertoire, for they make up too vast a portion of the extant divine scenes. Virtually all the Olympic episodes in the Odyssey belong to this category, ${ }^{32}$ and several of the broader Iliadic ones portray a deity making some type of complaint or request to Zeus to which he has to respond. ${ }^{33} \mathrm{We}$ also find complaints and requests to Zeus in the Cyclic epics. ${ }^{34}$ They are therefore most likely to have been common in the Greek oral tradition, and earlier than the Iliad.

${ }^{29}$ Dike's usual dwelling is never specified by Hesiod, but 'elsewhere [in Greek poetry] Dike's seat beside Zeus is treated as something permanent', M.L. West, Hesiod. Works and Days (Oxford

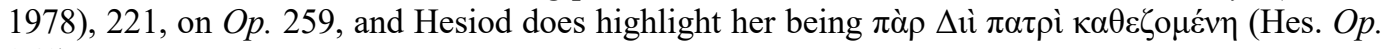
261).

${ }^{30}$ S.T. Reece, 'Type-scene', in M. Finkelberg (ed.), The Homer Encyclopedia (Oxford, 2011), which volume? 3.905-7, at 905. Note however that since W. Arend, Die Typischen Scenen bei Homer (Berlin, 1933), Homerists have broadened the spectrum to account for both typicality and considerable structural and verbal variation: see M. Edwards, 'Homer and oral tradition: the typescene', Oral Tradition 7/2 (1992), 284-330, at 290-8, J.M. Foley, Traditional Oral Epic (Berkeley, 1990), 140-5, M. Clark, 'Formulas, metre and type-scenes', in R. Fowler (ed.), The Cambridge Companion to Homer (Cambridge, 2004), 117-38, at 134-7, R. Friedrich, Post-Oral Homer (Stuttgart, 2019), 135-54. Varying views on the amount of innovation and terminological inconsistencies notwithstanding ('type-scene', 'scene type', 'sequence of motifs', 'theme', 'scene shape'), such recurrent structural features are considered traditional and inherited.

${ }^{31}$ Such as the one proposed for similes by Ready (n. 27), 201-38.

32 One could also include Od. 24.472-88 (and Il. 20.13-31), where Athena and Poseidon suspiciously enquire into Zeus' plan without explicitly voicing a preference; cf. also Od. 8.303-21.

${ }^{33}$ Hera at Il. 1.539-43, 4.24-9, 8.461-5, 16.439-43, Athena at 8.30-7, 22.177-81; cf. Il. 24.3176 (though Apollo addresses the gods generally).

${ }^{34}$ Proclus reports that in the Aethiopis Eos was able to confer immortality upon Memnon 'after

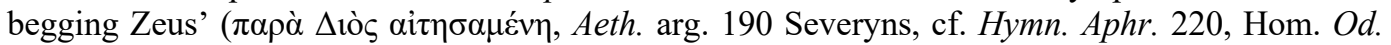
20.74), and it is possible that in the Nostoi, or towards the end of the Iliou persis, Athena, enraged at the lesser Ajax, complained to Zeus before arranging for the storm that caused the hero's death; cf. Il. pers. arg. 266-7 Severyns, Apollod. Epit. 6.5. See also Cypr. fr. 1 Bernabé (Ge complains to Zeus). 
To be sure, the triad of Iliadic scenes featuring Aphrodite, Ares and Artemis displays peculiarities of its own, probably signalling that Homer wished to connect them in the minds of his audiences. But this is no reason to utterly detach them from the broader group of divine complaint/request scenes. The factors that do set them apart, and this is a crucial point worth repeating, do not bring them any nearer to the Gilgamesh episode. For in none of the eleven scenes listed above is the deity physically hurt as Aphrodite, Ares and Artemis are-but neither is Ishtar. Neither Aphrodite nor Artemis has anything specific to ask of Zeus, but this is the case with Ishtar and Anu as it is in the other Greek cases. Ares is more specific about Athena, and able to upset Zeus, as Ishtar upsets Anu. But the Iliad's divine narrative is systematically conflictual. Zeus is upset by Thetis (Il. 1.517-21, in another 'arrival

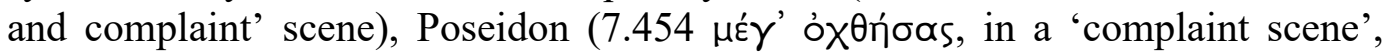
15.162-7), Athena (8.401-6), Hera (1.565-7, 4.30-42, 15.13-33), and the gods as a group (8.18-27). It is thus difficult to see why Gilgamesh would offer a closer or historically more relevant comparandum to the Ares-Zeus exchange than the poet's own practice. It may also be noted here that Ishtar's decisive menace toward Anu (she will release the dead from Hell if she does not obtain the Bull of Heaven), is partially paralleled in Helios' threat to shine in Hades. ${ }^{35}$

Let us draw some preliminary conclusions. Aphrodite's and Ishtar's ascents are quite different in structure and ethos. The Greek episode, with its closest Iliadic relatives, can and should be situated among a wider family of similar scenes. The Babylonian episode is, in many important respects (absence of physical abuse, actual request of some cosmic or narrative importance, and threat), closer to other Greek Olympian scenes than to the Iliadic ones to which it is usually compared. A Greek scene's traditional status cannot rule out its being part and instrument of a cross-cultural imitative process, but it can make this hypothesis unnecessary. We can at least suppose that, from a structural and compositional perspective, Homer's Greek traditional background may have been more important than Gilgamesh. ${ }^{36}$

If the structure is traditional, there remains the protagonists' identity. Zeus, the chief to whom the other gods complain, would not easily suggest a foreign Sky god. Aphrodite is indeed a partial Greek counterpart to Ishtar, but not here: the erotic

\footnotetext{
${ }^{35}$ Gresseth (n. 1), 15 n. 24. Cf. below n. 83.

36 The same holds true for Gilgamesh's catalogue of Ishtar's lovers (SB Gilg. VI 44-79) and Dione's catalogue of gods in pain, which Currie (2016), 178-89 sees as interacting, alongside Zeus' at Il. 15.315-28, Calypso's at Od. 5.121-9 and Hymn. Aphr. 202-40; differently Kelly (n. 3, 2008), 289-90. Note that Dione's is the least close of the four to the Babylonian catalogue, with which it shares neither function nor subject. Contrary to the interrelated Iliadic divine ascent scenes, moreover, there is no obvious intra-textual nexus between Dione's and Zeus' catalogues. On Dione's paradeigma see B. Sammons, The Art and Rhetoric of the Homeric Catalogue (Oxford, 2010), 2438, and Sekita (n. 17). On Gilgamesh's and Calypso's catalogues see C. Metcalf, 'Calypso and the Underworld: the limits of comparison', in W. Heizmann and M. Egeler (eds.), Between the Worlds. Contexts, Sources, and Analogues of Scandinavian Otherworld Journeys (Berlin, forthcoming), 421-35, at 427-30, pointing to a Sumerian catalogue of Innana's enemies. W.G.E. Watson (N.A.B.U. 2019/72) discusses Ugaritic parallels to Ishtar's 'catalogue' at SB Gilg. VI 7-21. See §§45 below on widespread typical motifs across traditions.
} 
element underlying Gilgamesh's slander has left no obvious traces in our scene. ${ }^{37}$ Then we have Dione.

\section{DIONE AND HOMER'S DIVINE NARRATIVE}

A 'calque on Antu' according to Burkert, Dione was, in fact, hardly invented by Homer for this scene. ${ }^{38}$ Beyond the virtual irrelevance of Antu in the Babylonian episode which we noted above, it is good to remember that Dione was quite well established in the early Greek pantheon as one of the powerful wives of Zeus whom Hera tends to oppose. Since she is effectively the scene's main character, a full consideration of her role and position helps understanding this episode within Homer's divine narrative.

It has been plausibly argued that Hesiod's account of Aphrodite's motherless birth (Theogony 188-200) combines Greek elements, especially in the etymological aetiology, with Near Eastern ones - the descent from Uranus and the birth as a result of castration. ${ }^{39}$ In this view, Hesiod's genealogy is decidedly more 'orientalizing' than Homer's. Given Hesiod's choice of such an aetiology for Aphrodite's birth, it is not surprising to find Dione relegated to the catalogue of the many daughters of Oceanus (353). ${ }^{40}$ Crucially, nevertheless, when the Muses sing about many of the most important deities in the Theogony's proem, no daughter of Oceanus is recalled in their short catalogue, but Dione does find her place there, quite close to Aphrodite and, unsurprisingly, to 'another matron' (so West), Leto $(16-18) .{ }^{41}$

Dione's stable and traditional place among the senior goddesses, and her connection with Leto, is confirmed by the Homeric Hymn to Apollo, where Dione

\footnotetext{
${ }^{37}$ Currie (2016), 175 notes Athena's caustic reference to her sister's habit of driving Greek women into the arms of Trojan men (Il. 5.421-5), a transparent allusion to the abduction of Helen and the Parisurteil, and to Aphrodite's abduction of Paris from Menelaus' hands at Il. 3.382-447. The erotic overtones in these episodes would signal that in our heavenly scene 'the Iliad still appears to know and to exploit the [Gilgamesh] scene's associations with seduction sequences', namely Gilgamesh's re-use of Dumuzi-Innana songs (ibid., 169-73). The hypothesis of a Homeric connection between Diomedes and Gilgamesh rests uniquely on the former playing Achilles' part (Achilles being seen as the primary Iliadic Gilgamesh-figure); cf. Currie (2016), 197. But the exploration of human/heroic limits in respect to divinity is not exclusive to Gilgamesh, Achilles and Diomedes. If the Tydides is to be attributed a meta-Iliadic dimension here, one might recall Thebaid fr. 9 Bernabé, where Athena's bestowing of immortality to Diomedes is envisaged as a result of his father's impiety: the implications of divine aid in Diomedes' 'super-human' aristeia intersect with a broader Iliadic discourse on his worth compared to Tydeus. See recently J.P. Christensen and E. Barker, 'On not remembering Tydeus: Agamemnon, Diomedes and the contest for Thebes', MD 66 (2011), 9-44, B. Sammons, 'A tale of Tydeus: exemplarity and structure in two Homeric insets', TiC 6 (2014), 297-318.

${ }^{38}$ Burkert (1992), 98.

${ }^{39}$ Cf. P. Pucci, Inno alle Muse (Esiodo, Teogonia 1-115), (Pisa, 2007), 52 on Theog. 16: 'il culto di Afrodite Urania, venuto dall'Oriente, le sottrasse [sc. a Dione] la maternità di Afrodite.' See Metcalf (n. 3), 170-90.

${ }^{40}$ According to S.L. Budin, The Origin of Aphrodite (Bethesda, 2003), 22 n. 28, Theog. 353 attests to an aquatic connection between Dione and Aphrodite.

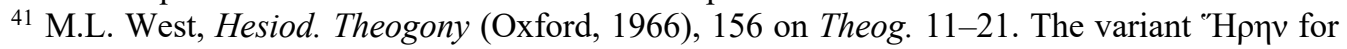
"H $\beta \eta v$ at Theog. 17 (Plut. Quaest. Conv. 747E) is probably of little significance.
} 


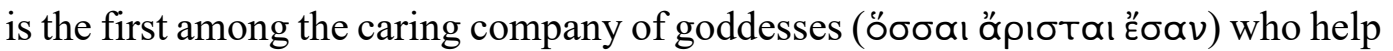
Leto have a safe birth-giving, Hera's enmity notwithstanding (Hym. Ap. 92-6). The same enmity, it should be noted, emerges from the scene in Iliad Book 21, where Artemis, maltreated by Hera, leaves her bow behind and flies to Olympus. Leto, whose power as elder 'wife of Zeus' is highlighted by Hermes (Il. 21.496-501), picks up her daughter's bow and goes after her. The contrast between Leto's motherly care and Hera's hatred is analogous to what we find in Iliad 5 in reference to Dione. Aphrodite and Artemis, who support the Trojans, are humiliated by the most powerful pro-Achaean goddesses, respectively Athena and Hera, and both are supported by their mothers, Dione and Leto. ${ }^{42}$ These elder goddesses are portrayed as caring and gentle, in contrast with a wrathful Hera, just as Artemis and Aphrodite stand in opposition to Athena. ${ }^{43}$

There is no reason to suppose that the Hymn to Apollo is imitating the Iliad here; once again, rather, Dione's role as a senior goddess is helpful in displaying the wellestablished opposition within the Olympian extended family and Hera's general hostility toward Zeus's offspring. ${ }^{44}$ Within the surviving corpus of early Greek epic, Dione's motherly connection to Aphrodite is exploited only in the Iliad, but the love-goddess' widespread epithet $\Delta$ iòs $\theta u \gamma$ ótnp indirectly attests to the preHomeric character of this nexus - or, at the very least, to a different genealogy than Hesiod's. ${ }^{45}$ The presence of Dione in Book 5, in connection with Leto's in Book 21 , responds in the first place to the logic of the Iliad's divine system, and to the broader traditional mythology concerning Zeus and his wives.

The opaque remains of Orphic theogonies shed further light on Dione. In one fragment listing the female Titans (Orph. fr. 179 Bernabé), Dione stands among all the goddesses mentioned by Hesiod, Theogony $135-6$ (where she is absent). ${ }^{46}$ Our source, Proclus, probably read these lines in the so-called Orphic Rhapsodies, a collection put together sometime in the Christian era, or shortly before, which undoubtedly contained much older material. ${ }^{47}$ This catalogue's relative antiquity, including the presence of Dione, is warranted by the occurrence of an almost identical sequence in Apollodorus and his source, possibly the Cyclic Theogony. ${ }^{48}$

42 On connections between Iliad Books 5 and 21 see above n. 20.

${ }^{43}$ Note further that Aeneas is cured by Artemis and Leto at $\mathrm{Il}$. 5.445-8.

${ }^{44}$ Hera's jealousy and hostility are central to the Hymn to Apollo, and pervasive in early Greek epic. See A. Bonnafé, Eros et Eris: Mariages divins et mythe de succession chez Hésiode (Lyon, 1985); on this hymn: J.S. Clay, The Politics of Olympus (London, 2006²), 19-74; on Iliadic ramifications: A. Kelly, A Referential Commentary and Lexicon to Homer Iliad VIII (Oxford, 2007), $420-5$.

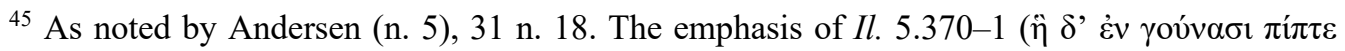

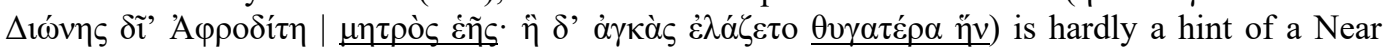
Eastern connection, though it might be taken as advertising this genealogy as distinct from the Hesiodic one.

46 Procl. in Pl. Ti. 3.184 Diehl. Cf. M.L. West, The Orphic Poems (Oxford, 1983), 121-4.

${ }^{47}$ See D.A. Meisner, Orphic Tradition and the Birth of the Gods (Oxford, 2019), 170-87.

${ }^{48}$ Apollod. Bibl. 1.1.2, with P. Scarpi, Apollodoro. Biblioteca (Milano, 1996), 419-20. On the Cyclic Theogony as a possible source here cf. West (n. 46), 125-6, L. Brisson, Orphée et l'Orphisme à l'époque imperiale (Aldershot, 1995), 404-7; cf. G.B. D’Alessio, 'Theogony and Titanomachy', in M. Fantuzzi and C. Tsagalis (edd.), The Epic Cycle and its Ancient Reception. A Companion (Cambridge, 2015), 199-212, at 199-202. 
Moreover, the Rhapsodies seem to have featured two births of Aphrodite. The first (Orph. fr. 189 Bernabé), similar to Hesiod's, was from castration, the second is from

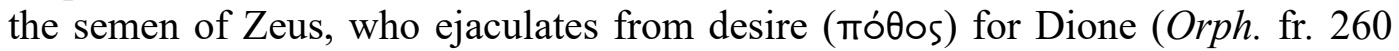
Bernabé). ${ }^{49}$ According to West's reconstruction, in the 'Eudemian Theogony' supposedly known to Eudemus, Aristoteles and Plato, Aphrodite was born from Zeus and Dione, and this was also the version in the Cyclic Theogony mentioned above. ${ }^{50}$ Though Near Eastern influence on Orphic cosmogonies is pervasive, ${ }^{51}$ the role of Dione as a Titan, wife of Zeus and mother of Aphrodite should be traced back to her position in the Greek epic tradition, as attested (not invented) by Homer. ${ }^{52}$

Plato famously distinguishes between the Uranian Aphrodite and the Aphrodite

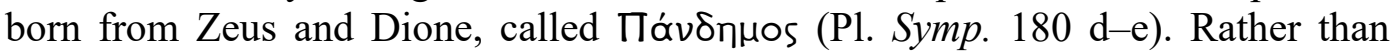
Homer, the latter evokes an Attic ritual and civic dimension. ${ }^{53}$ It is in the realm of cult that we find further evidence of Dione's position. An inscription dated 409-408 B.C. attests to a $\beta \omega \mu$ ós of Dione in Athens' acropolis. ${ }^{54}$ Her association with Zeus in his sanctuary and oracle at Dodona is well known, and Zeus $\Delta \omega \delta \omega v \alpha i$ os is known to Homer (Il. 16.223). Burkert refers to Strabo (7.7.12), who explains a change in the cult as due to a later introduction of Dione, ${ }^{55}$ but the geographer's theory is rejected by modern scholarship. In W.H. Parke's words, the evidence shows 'no support for a post-Homeric introduction of the cult of Dione', and it is very likely that Dione 'had been present at Dodona as Zeus's female consort since time immemorial. ${ }^{56}$

\footnotetext{
${ }^{49}$ Procl. in Pl. Cra. 110.23-111.5 Pasquali= G. Pasquali, Procli Diadochi in Platonis Cratylum Commentaria (Leipzig, 1908), 110 line 23 - 111 line 5.

${ }^{50}$ West (n. 46), 116-21, 125-7.

${ }^{51}$ López Ruiz (n. 6), 130-70, Meisner (n. 47), 18-33 and passim.

${ }^{52}$ Cassio (n. 5), 420 n. 39 notes that Philo of Byblos FGrHist 790 F 2 (35) equates Dione to

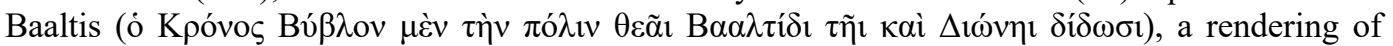

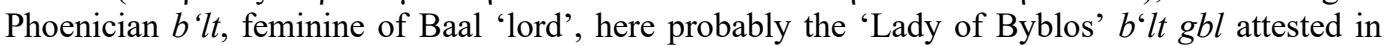
Phoenician inscriptions, possibly Asherah (El's consort at Ugarit): see A.I. Baumgarten, The Phoenician History of Philo of Byblos (Leiden, 1981), 201, 223-4 n. 58 and H.W. Attridge and R.A. Oden, Jr., Philo of Byblos. The Phoenician History (Washington, DC, 1981), 88-9 n. 100, 91-2 n. 132. In Philo Dione/Baaltis is daughter of Uranus and one of the wives of Elos/Kronos $(=\mathrm{El})$, FGrHist 790 F 2 (22-4). This seems to attest to Dione's solid position as a Titan in the Greek system, which facilitated interpretatio. Philo's polemical views on Greek divine equations can be read at FGrHist 790 F 2 (8).

${ }^{53}$ On the general distance between Athenian myth and cult and the epic tradition see R. Parker, 'Myths of early Athens', in J. Bremmer (ed.), Interpretations of Greek Mythology (London, 1986),

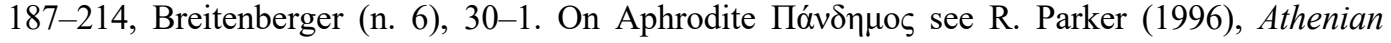
Religion. A History (Oxford, 1996), 48-9; id., Polytheism and Society at Athens (Oxford, 2005), 407-8; V. Pirenne-Delforge, L'Aphrodite grecque (Paris, 1994), 26-40; Breitenberger (n. 6), 30-44.

${ }^{54}$ SEG 10.281, possibly also SEG 3.35 (c. 420 B.C., rations of Eleusinian goddesses, Dione's name restored). On the importance of the oracle and cult of Zeus and Dione in fourth-century Athens see Dem. Fals. leg. 229, with W.H. Parke, The Oracles of Zeus. Dodona, Olympia, Ammon (Oxford, 1967), 138-43; cf. E. Simon, 'Dione', LIMC III.1, 411-13.

${ }^{55}$ Burkert (1992), 205 n. 8.

${ }^{56}$ Parke (n. 54), 69-70, cf. Simon (n. 54), 411. Dione stands firmly at the side of Zeus as soon as the epigraphic record for 'enquiries' to the oracle begins (fifth century B.C.): Parke (n. 54), 25962.
} 
Indeed, the Dodoneian pair has been connected to the feminine theonym diwija/diuja attested in Mycenaean tablets, ${ }^{57}$ since this is the feminine counterpart of Zeus's name (myc. *diweus), ${ }^{58}$ and the name $\Delta \mathrm{I} \omega \nu \eta$ 'is the Ionic outcome of an earlier * $\Delta \mathrm{I} F-\omega \dot{v} \alpha-$, where $\Delta \mathrm{I} F-$ is the zero grade of the root of Zeús and $-\omega \nu \bar{\alpha}$ is a suffix made up of Indo-European ingredients. ${ }^{59}$ A direct relation between diwija/diuja and Dione, though widely maintained, is not supported by these (different) name formations. ${ }^{60}$ One should however note that a possible reading of pe-re-*82, close to diuja in tablet PY Tn 316 and likely a theonym, is pe-re-ja $/$ wja $=\pi \varepsilon \dot{ } \lambda \varepsilon ı \alpha$ 'dove-goddess', matching the $\pi \varepsilon ́ \lambda \varepsilon ı \alpha$ ('dove') typically associated with Dodona, and Aphrodite. ${ }^{61}$ Yet there is no agreement on how to read phonograph *82. ${ }^{62}$ Thus, while it is perhaps incautious to state that 'Zeus's first wife was Dione', ${ }^{63}$ there is certainly no dearth of evidence for Dione's integration in the divine system of early Greek epic poetry, nor in cult nor, indeed, in aspects of the Orphic tradition which probably reach back well into the archaic period.

We cannot altogether exclude that Homer reactivated Dione's name to construe an interaction with Antu. ${ }^{64}$ But this survey indicates that Dione's persona as an elder goddess, one of Zeus's wives, was probably fully traditional, and became in Homer a function of the divine opposition staged throughout the Iliad and revolving around the Judgment of Paris. This is an important part of what the poet achieves by connecting the divine ascents in Books 5 and 21, which were composed against a traditional background of divine complaints and requests to Zeus. The hypothesis of a Babylonian imitation is unnecessary to appreciate Homer's technique, and his discourse on the gods should probably not be interpreted on that basis. The scene's form and purposes are thus entirely consistent with a genesis within the Greek traditional poetic universe.

${ }^{57}$ F. Rougemont, 'Les noms des dieux dans les tablettes inscrites en linéaire B', in N. Belayche et al. (edd.), Nommer les dieux. Théonymes, épithètes, épiclèses dans l'antiquité (Turnhout, 2005), 325-88, at 337-8 n. 63 and 372-3: PY Cn 1287.6, Tn 316 v.6, An 607.5, TH Ft 278, Gp 313.2, and Gp 109.1 (to be rejected); KN Xd 97 (dubious): M. Gérard-Rousseau, Les mentions religieuses dans les tablettes mycéniennes (Rome, 1968), 68.

${ }^{58}$ P. Lévêque, 'Le syncrétisme créto-mycénien', in F. Dunand and P. Lévêque, Les syncrétismes dans les religions de l'antiquité (Leiden, 1975), 19-73, at 42 n. 117, G.E. Dunkel, 'Vater Himmels Gattin', Die Sprache 34 (1988-90), 1-26, at 15.

${ }^{59}$ Cassio (n. 5), 420 n. 37, cf. Burkert (1992), 205 n. 8, Dunkel (n. 58), 16, 21-6.

${ }^{60}$ The connection is accepted by Budin (n. 40), 283; S. Pulleyn, 'Homer's religion: philological perspectives from Indo-European and Semitic', in M. Clarke, B. Currie and R. Lyne (edd.), Epic Interactions (Oxford, 2006), 47-74, at 59-61; and A. Teffeteller, 'The song of Ares and Aphrodite: Ašertu on Skheria', in A. Smith and S. Pickup (edd.), Brill's Companion to Aphrodite (Leiden, 2010), 133-50, at 142-3. But neither Dunkel (n. 59) nor M.L. West, Indo-European Poetry and Myth (Oxford, 2007), 192-3 identifies diwija with Dione.

${ }^{61}$ Budin (n. 40), 46 n. 44. On doves and Dodona see Breitenberger (n. 5), 15-20, who sees this cultic background behind Homer's scene, alongside the Gilgamesh influence.

${ }^{62}$ See Gérard-Rousseau (n. 57), 174-6, Rougemont (n. 57), 338 n. 64, I. Rutherford, 'Mycenaean Religion', in M.R. Salzman (ed.), The Cambridge History of Religions in the Ancient World (Cambridge, 2012), 256-79, at 258-9.

63 J.N. Bremmer, Greek Religion (with addenda) (Cambridge, 1999), 16.

${ }^{64}$ Currie (2016), 167 n. 123: 'A feminine theonym "Dione" was probably just exploited, rather than invented, for this episode.' 


\section{TOWARDS A NEAR EASTERN PICTURE}

The early Greek traditional poetic universe, however, is not to be detached from the earlier and contemporary poetic traditions of the Near East. In this section, we will test a systematic approach to the 'complaint/request in heaven' topos. One aim is to see whether we can identify a comparable typology in which we may situate the Gilgamesh episode, just as was done for Homer's scene. The major advantage is gaining an analytical framework to address the comparison from a holistic perspective.

Drifting down the 'broad stream of international tradition' that constitutes the Near Eastern context of Homer's divine machinery, ${ }^{65}$ West enlarged Burkert's oneon-one perspective, noting that Ishtar's revilement and request for vengeance is also paralleled in the Ugaritic Aqhat epic (thirteenth century B.C.). The divine maiden Anat requests Aqhat's bow, offering immortality, but the young man refuses saying that bows are inappropriate for women. Thus Anat visits and violently menaces the chief god $\mathrm{El}$ in order to take revenge. West further compares Ishtar's threat to release the dead at SB Gilg. VI 97-100 to Helios' at Od. 12.380-2 (and to Hades' fears at $I l$. 20.61-5), noting that her complaint also parallels Dike's in Hesiod, $O p$. 258-62 and that of the Litai at Il. 9.510-12. Both Ishtar's and Anat's requests are moreover associated with Thetis' at $I l$. 1.493-530, which is in turn juxtaposed to Ningal's plea to the chief gods An and Enlil in the Sumerian Lament for Ur (twentieth century B.C.). ${ }^{66}$ In his argument for a direct line of reception from SB Gilgamesh to the Iliad, Currie adds to the Aqhat episode a Hurro-Hittite failed seduction and ascent in tears (Shaushka rejected by Ullikummi, the heavenly scene being lost), and Ereshkigal's request to get back her partner Nergal (through her messenger Namtar) in the Babylonian Nergal and Ereshkigal (first attested fourteenth century B.C.). ${ }^{67}$

Just how the multiplicity of Near Eastern parallels should affect comparative enquiries remains a fundamental question. In one view, we should choose between seeing transfers of (clusters of) free-floating motifs or mythemes, or integral narrative episodes coming from one recognisable source. ${ }^{68}$ But a more productive way of considering the question might be, at a preliminary stage, to fully embrace the Near Eastern and Greek multiplicity and variety, and assess the similarities as attesting to a commensurate compositional syntax. Rather than tracing reception stemmata (which remains a legitimate, if difficult, enterprise), we will attempt to recover a broader framework for systematic interpretation. The following chart offers a synopsis of divine complaint/request scenes in Near Eastern narratives, without presumption of completeness. ${ }^{69}$

\footnotetext{
${ }^{65}$ West (1997), 401.

${ }^{66}$ West (1997), 180, 353-4, 362, 373, 390-1, 412.

${ }^{67}$ Currie (2016), 193-5: the three episodes are deemed to likely derive from the Gilgamesh tradition, but see below n. 83 .

${ }^{68}$ Currie (2016), 195.

${ }^{69}$ The inclusion of Sumerian City Laments (not strictly narrative texts) might be justified by the precedent of West (1997), 353. The line-numbering of all Sumerian texts refers to ETCSL (http://etcsl.orinst.ox.ac.uk/): for updated editions and translations (where available), or relevant references, see P. Attinger's webpage (http://www.iaw.unibe.ch/attinger/). Akkadian editions: P.
} 


\begin{tabular}{|c|c|c|c|c|}
\hline & Lines & Approach & For whom & Why \\
\hline \multicolumn{5}{|l|}{ SUMERIAN } \\
\hline $\begin{array}{l}\text { Bilgames and } \\
\text { the Bull of } \\
\text { Heaven }(B B H)\end{array}$ & Seg. B 31-54 & Direct $(\rightarrow$ An $)$ & $\begin{array}{l}\text { Herself } \\
\text { (Innana) }\end{array}$ & $\begin{array}{l}\text { Reviled by } \\
\text { Bilgames }\end{array}$ \\
\hline $\begin{array}{l}\text { Innana and } \\
\text { Ebih (InEb) }\end{array}$ & $60-127$ & Direct $(\rightarrow$ An $)$ & $\begin{array}{l}\text { Herself } \\
\text { (Innana) }\end{array}$ & $\begin{array}{l}\text { Reviled by } \\
\text { Ebih }\end{array}$ \\
\hline $\begin{array}{l}\text { Innana and } \\
\text { Shukaletuda } \\
(\operatorname{In} \check{S})\end{array}$ & $239-251$ & Direct $(\rightarrow$ Enki) & $\begin{array}{l}\text { Herself } \\
\text { (Innana) }\end{array}$ & $\begin{array}{l}\text { Raped by } \\
\text { Shukaletuda }\end{array}$ \\
\hline $\begin{array}{l}\text { Enki and the } \\
\text { World Order } \\
(E W O)\end{array}$ & 387-end & Direct $(\rightarrow$ Enki) & $\begin{array}{l}\text { Herself } \\
\text { (Innana) }\end{array}$ & $\begin{array}{l}\text { Lack of } \\
\text { honours }\end{array}$ \\
\hline $\begin{array}{l}\text { Innana and } \\
\text { Enki (InEn) }\end{array}$ & Segs. B-D & Direct $(\rightarrow$ Enki) & $\begin{array}{l}\text { Herself } \\
\text { (Innana) }\end{array}$ & $\begin{array}{l}\text { Lack of } \\
\text { honours }\end{array}$ \\
\hline $\begin{array}{l}\text { Innana's } \\
\text { Descent to the } \\
\text { Netherworld } \\
(\text { InD) }\end{array}$ & $173-253$ & $\begin{array}{l}\text { Divine helper } \\
\text { Ninshubura } \\
(\rightarrow \text { Enlil, Nanna, } \\
\text { Enki) } \\
\end{array}$ & Innana & $\begin{array}{l}\text { Tricked by } \\
\text { Ereshkigal }\end{array}$ \\
\hline $\begin{array}{l}\text { Lament for } \\
\text { Sumer and } U r \\
(L S U r)\end{array}$ & $\begin{array}{l}340-70 \\
449-74\end{array}$ & $\begin{array}{l}\text { Direct } \\
(\rightarrow \text { Enlil })\end{array}$ & $\begin{array}{l}\text { Himself } \\
\text { (Nanna) and } \\
\text { city }\end{array}$ & $\begin{array}{l}\text { Land } \\
\text { devastated }\end{array}$ \\
\hline $\begin{array}{l}\text { Lament for } U r \\
(L U r)\end{array}$ & $144-68$ & $\begin{array}{l}\text { Direct } \\
(\rightarrow \text { An and Enlil })\end{array}$ & $\begin{array}{l}\text { Herself } \\
\text { (Ningal) and } \\
\text { city }\end{array}$ & $\begin{array}{l}\text { Land } \\
\text { devastated }\end{array}$ \\
\hline \multicolumn{5}{|l|}{ AKKADIAN } \\
\hline $\begin{array}{l}\text { Ishtar's Descent } \\
\text { to the } \\
\text { Netherworld } \\
(I \check{s} D)\end{array}$ & $81-99$ & $\begin{array}{l}\text { Divine helper } \\
\text { Papsukkal }(\rightarrow \mathrm{Ea})\end{array}$ & Ishtar & $\begin{array}{l}\text { Tricked by } \\
\text { Ereshkigal }\end{array}$ \\
\hline $\begin{array}{l}\text { Nergal and } \\
\text { Ereshkigal } \\
(N \& E)\end{array}$ & $320-36$ & $\begin{array}{l}\text { Divine helper } \\
\text { Namtar }(\rightarrow \text { divine } \\
\text { assembly })\end{array}$ & Ereshkigal & $\begin{array}{l}\text { Reviled by } \\
\text { Nergal }\end{array}$ \\
\hline
\end{tabular}

Lapinkivi, The Neo-Assyrian Myth of Ištar's Descent and Resurrection (Helsinki, 2010); S. Ponchia and M. Luukko, The Standard Babylonian Myth of Nergal and Ereškigal (Helsinki, 2013); W.G. Lambert, Babylonian Creation Myths (Winona Lake, 2013) (for Enüma elish); L. Cagni, L'Epopea di Erra (Roma, 1969); all texts translated in B. Foster, Before the Muses. An Anthology of Akkadian Literature (Bethesda, 20053). KTU: M. Dietrich, O. Loretz and J. Sanmartín (edd.), Die keilalphabetischen Texte aus Ugarit, Ras Ibn Hani und anderen Orten (Münster, 2013³); translations in S.B. Parker (ed.), Ugaritic Narrative Poetry (Atlanta, 1997). CTH: E. Laroche, Catalogue des Textes Hittites (Paris, 1971); online corpus, with editions and German translations, at E. Rieken et al., Mythen der Hethiter (2009-), www.hethiter.net/txhet_myth; also H.A. Hoffner Jr., Hittite Myths (Atlanta, 1998 ${ }^{2}$. All online resources accessed 6 April 2020. 


\begin{tabular}{|c|c|c|c|c|}
\hline $\begin{array}{l}\text { Enūma elish } \\
(E e)\end{array}$ & I 29-54 & Direct $(\rightarrow$ Tiāmtu) & $\begin{array}{l}\text { Himself } \\
\text { (Apsû) }\end{array}$ & $\begin{array}{l}\text { Disturbed } \\
\text { by younger } \\
\text { gods }\end{array}$ \\
\hline $\begin{array}{l}\text { Erra and Ishum } \\
(\text { Erra })\end{array}$ & I 125-91 & Direct $(\rightarrow$ Marduk) & Himself (Erra) & $\begin{array}{l}\text { Reviled by } \\
\text { mankind }\end{array}$ \\
\hline \multicolumn{5}{|l|}{ UGARITIC } \\
\hline Baal Cycle & $\begin{array}{l}\text { KTU 1.3.v } \\
\& 1.4 . i v-\mathrm{v}\end{array}$ & $\begin{array}{l}\text { Divine helpers } \\
\text { Anat \& Asherah } \\
(\rightarrow \mathrm{El})\end{array}$ & Baal & $\begin{array}{l}\text { Lack of } \\
\text { honours } \\
\text { (abode) }\end{array}$ \\
\hline Aqhat & $\begin{array}{l}\text { KTU } \\
\text { 1.17.i.15-48 } \\
\text { 1.17.vi-18.i }\end{array}$ & $\begin{array}{l}\text { Divine helper Baal } \\
(\rightarrow \mathrm{El}) \\
\text { Direct }(\rightarrow \mathrm{El})\end{array}$ & $\begin{array}{l}\begin{array}{l}\text { Daniel } \\
\text { (mortal) }\end{array} \\
\text { Herself (Anat) }\end{array}$ & $\begin{array}{l}\text { Lack of heir } \\
\text { Reviled by } \\
\text { Aqhat }\end{array}$ \\
\hline \multicolumn{5}{|l|}{$\begin{array}{l}\text { (HURRO-) } \\
\text { HITTITE }\end{array}$} \\
\hline $\begin{array}{l}\text { Appu and his } \\
\text { two sons }\end{array}$ & $\begin{array}{l}\text { CTH } \\
360.1 .1 i .1-31\end{array}$ & $\begin{array}{l}\text { Divine helper Sun- } \\
\text { God } \\
(\rightarrow \text { Teshshub })\end{array}$ & $\begin{array}{l}\text { Appu } \\
\text { (mortal) }\end{array}$ & Lack of heir \\
\hline $\begin{array}{l}\text { Elkunirsha and } \\
\text { Ashertu }\end{array}$ & $\begin{array}{l}\text { СТH } \\
342.1 .1-2 .\end{array}$ & $\begin{array}{l}\text { Direct } \\
(\rightarrow \text { Elkunirsha }) \\
\text { Direct } \\
(\rightarrow \text { Elkunirsha })\end{array}$ & $\begin{array}{l}\text { Himself } \\
\text { (Storm God) } \\
\text { Herself } \\
\text { (Ashertu) }\end{array}$ & $\begin{array}{l}\text { Assaulted } \\
\text { by Ashertu } \\
\text { Reviled by } \\
\text { the Storm } \\
\text { God }\end{array}$ \\
\hline $\begin{array}{l}\text { Song of } \\
\text { Ullikummi }\end{array}$ & $\begin{array}{l}\text { CTH } \\
\text { 345.I.2.ii.26, } \\
-31{ }^{\prime}\end{array}$ & $\begin{array}{l}\text { Direct } \\
(\rightarrow \text { Teshshub?) }\end{array}$ & $\begin{array}{l}\text { Herself } \\
\text { (Shaushka) }\end{array}$ & $\begin{array}{l}\text { Rebuffed by } \\
\text { Ullikummi }\end{array}$ \\
\hline
\end{tabular}

As in Greece, variations abound in such contextually determined situations. A detailed treatment of each scene is beyond the scope of this article; nor should we disregard their profound diachrony and geographical span. The Sumerian sources belong to the twentieth to sixteenth century B.C. and are likely to reflect earlier poetry, the Akkadian ones are mostly attested in the early first millennium, the Hurro-Hittite and Ugaritic texts in the late Bronze Age. But some structural and interpretative categories emerging from these complaint/request scenes are perfectly applicable to the Greek ones. They attest to the conventional and conservative nature of this topos and help us better understand what is at stake for divine characterisation and narrative function.

One difference is that the Greek gods' complaints are more often caused by mortals than by other supernatural beings. This probably reflects the hexametric corpus' generally heroic focus, whereas purely divine narratives prevail in Near Eastern sources. Still, when humans are involved, we do find complaints and requests relating to a mortal (BBH, SB Gilg., Aqhat, Appu and His Two Sons). The 
same circumstance may explain that whenever the complaint/request is raised on account of someone else, in Greek epic this protégé is always a mortal (and Zeus is never approached by a deity's delegate). ${ }^{70}$

Though intermediaries are not uncommon, the upset Near Eastern deity usually approaches the highest god in person. ${ }^{71}$ The causes of the protagonists' displeasure fall into two categories: they are either upset by another figure, be it supernatural (InEb, $N \& E, E e$ ) or mortal (In ̌́, BBH, SB Gilg., Erra, Aqhat), or perceive a lack of due honours (EWO, InEn, Baal Cycle). But since the offence is generally viewed as diminishing or threatening the deity's prerogatives, these categories often overlap, and the complaint/request scene stages a definition of the deity's character and cosmic position.

In the two Sumerian City Laments, the Land will thrive again under the protection of the lamenting deities, and Nanna and Ningal confirm their status as protectors of the city, embodying its suffering and recovery. ${ }^{72}$ In Innana and Ebih, Innana seeks revenge against the Ebih, the personified mountain region refusing to submit to her; she ignores An's counsels and departs raising a tremendous storm. Despite the erotic context, also Bilgames and the Bull of Heaven, like the derived Gilgamesh episode, also showcases Innana's character as the dreadful and powerful warrior goddess whose words even the great gods cannot withstand. ${ }^{73}$ With Enki, god of craft and wisdom, she is generally more cunning as she seeks to obtain the 'me', the divine prerogatives (InEn, EWO; InD, cf. Is $D$ ), and not particularly menacing even when violated by Shukaletuda $(\operatorname{InS})$. Forcefully or deviously, Innana/Ishtar always confirms or strengthens her power. The same applies to the Queen of the Netherworld Ereshkigal, whose threat to release the dead convinces the gods, and manifests how seriously she is to be taken in order to preserve cosmic stability.

The request scenes in the Ugaritic Baal Cycle aim at the construction of a House for Baal, the eventual recognition of his status as major deity. They also differentiate the intermediaries' personalities: impetuous Anat fails, wise Asherah

\footnotetext{
${ }^{70}$ Near Eastern cases that parallel the occasional absence of a journey (noted above) include EWO, LSUr, LUr, Aqhat (KTU 1.17.i.15-16). In Elkunirsha and Ashertu, the beginning of Ashertu's conversation with Elkunirsha is not preserved. A.R. George, 'How women weep? Reflections on a passage of Bilgames and the Bull of Heaven', in S. Parpola and R. Whiting (edd.), Sex and Gender in the Ancient Near East (Helsinki, 2002), 141-50, at 149, holds that An finds Innana weeping, but there is nothing in the text to exclude that it is the goddess who approached the chief god, as in SB Gilg. and the remaining Sumerian instances of the topos.

${ }^{71}$ Instead of a single ruler, the Sumero-Akkadian tradition presents the divine triad An(/u), Enlil and Enki/Ea (portrayed as a group in Nergal and Ereshkigal). In Enūma elish, the complaint is brought to Tiāmtu, who at that point represents the most powerful deity. In Erra and Ishum the protagonist addresses Marduk, as the poem accords with the Enuma elish theology, with Marduk as king of the gods.

72 Though the chief gods' relenting is not narrated in $L U r$, it is envisaged through the final prayers (LUr 378-410).

${ }^{73}$ On Innana's supremacy in Sumerian hymnology and mythology see A. Zgoll, Der Rechtsfall der En-ȟedu-Ana im Lied nin-me-šara (Münster, 1997), 81-6 and ch. 6; Metcalf (n. 3), 45-9.
} 
(El's own wife) succeeds. ${ }^{74}$ When Baal intercedes with El about Daniel's lack of an heir (compare the Hurro-Hittite Appu and His Two Sons, where the Sun God approaches Teshshub), Baal displays his role as protector of rulership. Endorsing Anat's vengeance against Aqhat, El deploys words that would perfectly suit Innana/Ishtar (KTU 1.18.i.16-19): ${ }^{.5}$

'I know you, daughter, as desperate,

[among goddesses no]thing resists you.

Go off, daughter, haughty of heart,

[lay] hold of what's in your liver,

set up the[ in] your breast.

To resist you is to be beaten.'

Definition of competences is central in the Greek tradition too. The 'allegories' of the Litai (Hom. Il. 9.510-12) and Dike (Hes. Op. 258-62) condemn an infringement on these deities' nature (refused 'Supplications', reviled 'Justice'). Thetis' success (Il. 1.493-532) exploits her being a disturbing element in Zeus's order, thereby stressing her power. ${ }^{76}$ Athena's Odyssean conversations with Zeus characterize her as the helper of the king deprived of his prerogatives, and show that the possibilities of her action, limited by Poseidon, ultimately depend on her father. ${ }^{77}$ Poseidon, who protests about his rights, is confirmed as the powerful god of natural catastrophes, on land (Il. 7.443-64) and sea (Od. 13.125-60), ${ }^{78}$ while Helios' menace and Zeus's quick answer (Od. 12.376-90), highlight the Sun's obvious importance for cosmic order. ${ }^{79}$ Ares, the war god driven out of battle, proves to be inferior to Athena in Zeus's preferences, but ends up sitting in glory at his side (Hom. Il. 5.864-906): war is hard to bear, but unavoidable. Zeus's words to Aphrodite at Il. 5.417-20 are best seen against this background. Thus, confronting the highest authority of the pantheon with a request or a complaint often contributes to defining a deity's sphere of competence in the divine and cosmic order, in these Near Eastern traditions as in Greece.

One cross-culturally shared pattern is that compensation or vengeance is generally achieved, but most often accompanied by some delay, whether or not in

${ }^{74}$ See M.S. Smith and W.T. Pitard, The Ugaritic Baal Cycle. Volume II. Introduction with Text, Translation and Commentary of KTU/CAT 1.3-1.4 (Leiden, 2009), 35-41; cf. n. 91 below. Similarly, Innana/Ishtar's helpers in $\operatorname{InD} / I_{\check{S}} \mathrm{D}$ emerge as resilient and trustworthy.

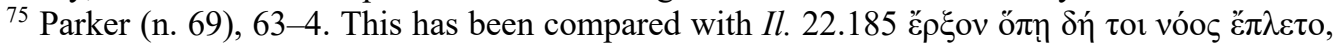

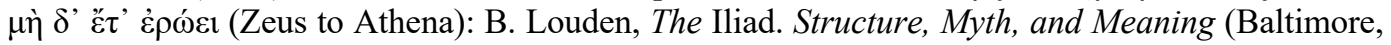
2006), 266-8; id., The Odyssey and the Near East (Cambridge, 2010), 23. The 'do as you wish'

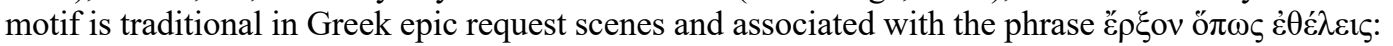
Hom. Il. 4.37 (in a broader divine assembly), Od. 13.145, 24.481; differently at Od. 16.67.

${ }^{76}$ L.M. Slatkin, The Power of Thetis and Selected Essays (Washington, DC, 2011), 30-95.

77 J.S. Clay, 'The beginning of the Odyssey', AJPh 97 (1971), 313-26, J. Marks, Zeus in the Odyssey (Washington, DC 2008).

${ }^{78}$ J. Maitland, 'Poseidon, walls, and narrative complexity in the Homeric Iliad', CQ 49 (1999), $1-13$.

${ }^{79}$ W. Allan, 'Divine justice and cosmic order in early Greek epic', JHS 126 (2006), 1-35, at 223. 
the form of lengthy negotiations. ${ }^{80}$ Some of these scenes unleash the entire poem's action: this applies to Enüma elish, Erra and Ishum, Aqhat, the Cypria (fr. 1 Bernabé), and both Homeric poems. ${ }^{81}$ Zeus's hesitation with Thetis and Athene at the beginning of the Homeric epics is reflected in considerable postponements, a long-term function of the plot: Zeus's active intervention starts in Iliad Book 8, and Odyssey Book 5. In Erra and Ishum, Marduk is understandably uncertain about handing over the reins of the cosmos to turbulent Erra: their long conversation amply foreshadows Erra's overturning of cosmic order (compare Zeus's awareness of Hera's reaction at $I l$. 1.517-21). Tiāmtu's hesitation towards Apsû's murderous plans in Enüma elish stresses the change in Tiāmtu, who will become herself the raging enemy of the younger gods after Apsû's conquest.

Repeated attempts structure narrative progression: Baal and Anat have to work hard to get the palace built; in Nergal and Ereshkigal, Namtar ascends to heaven several times, and Innana's emissary in Innana's Descent has to fail with Nanna/Sîn and Enlil before reaching Enki. ${ }^{82}$ Similarly, it is after Athena's second attempt that Zeus has Odysseus released from Calypso. Zeus does not hesitate much when confronting Poseidon and Helios, but the agreed intervention is either delayed (Il. 7.459-63, Od. 12.397-419) or displaced (Od. 13.153-8). That the requests in the Sumerian City-Laments are initially fruitless has a pathetic effect as part of the peripeteia. An(u)'s disagreements with Innana/Ishtar point to the goddess' determination; that Enki has to get drunk before Innana achieves her 'me' (InEn) highlights her cunning. In these ways, hesitations and delays stress the importance (and often the problematic nature) of the requests, serving also a variety of diegetic purposes.

We have shifted the comparison toward a culturally variegated, but recognisably integral, system of parallels. The numerous scenes where deities confront the chief gods with complaints and requests are construed in similar ways, and with similar purposes: they showcase the requesting deities' worth in the cosmos, and help the narrator unfold the tale through retardation and patterning. The scenes display similar compositional mechanisms with an analogous theological focus-factors that are significant for the question of literary diffusion.

\section{TRANSMISSIONS}

Before discussing diffusion towards Greece, it is worth considering transmission within the Near East. In the case of Akkadian versions of Sumerian forerunners (Ishtar's Descent, SB Gilgamesh), we can safely identify conscious redeployment.

\footnotetext{
${ }^{80}$ Cf. West (1997), 351-2. Some complaints are ineffectual: Anat's request to El (KTU 1.3.v) must fail for the long proceedings to be narrated; Zeus cannot give satisfaction to Ares (Hom. $I l$. 5.864-906), for he is still favouring the pro-Achaean deities who caused Ares' wound (with Zeus's approval).

${ }^{81}$ Cf. West (1997), 173-4 on divine conversations setting things in motion.

${ }^{82} \mathrm{Cf}$. Bilgames, Enkidu and the Netherworld (ETCSL 1.8.1.4.) 50-135, 221-37. The procedure is compressed in IšD 83-4 (CT 15: 46 rev. 3-4); cf. Lapinkivi (n. 69), 70-1.
} 
Elsewhere, direct reception among the examined Near Eastern scenes is difficult to pin down. ${ }^{83}$

An instructively cross-cultural occurrence of our topos comes in Elkunirsha and Ashertu, a fragmentary narrative attested in the Hittite capital Hattusa, in the Hittite language. ${ }^{84}$ The ruling divine couple Ashertu (West-Semitic Asherah) and Elkunirsha (West-Semitic El, cf. qône ereș, 'Creator of the Earth' in Genesis 14, 18-22), ${ }^{85}$ are involved in an interesting triangle with the Storm God, and the plot evolves through two complaints and requests to El. First the Storm God denounces Ashertu, whom he has rebuffed; then Ashertu denounces the Storm God, who has reviled her at Elkunirsha's suggestion-whereupon El agrees that Ashertu should stab the Storm God.

The two requests by different personae and the strongly violent tones remind one of the Ugaritic Baal Cycle and Aqhat. Indeed, Elkunirsha and Ashertu has traditionally been considered of Canaanite origin. ${ }^{86}$ But I. Singer has argued that this is, less restrictively, a "'West Semitic", "Amorite", or simply "'Syrian", tale, which should 'open up the perspective to a much broader cultural koine consisting of an intricate fusion of Semitic and Hurrian elements. ${ }^{\prime 87}$ As an index of the historical diffusion and translatability of our topos, this text alerts us to a current of late Bronze Age exchange (between Hurro-Hittite and West-Semitic areas) which does not seem obviously dependent on southern Mesopotamian literature. It is significant that the fragments of Elkunirsha and Ashertu belong to the same group of tablets as those preserving Ullikummi, the 'Kumarbi Cycle' narrative where we find Shaushka's failed seduction. ${ }^{88}$ The fact that the Hittite adaptations of

${ }^{83}$ Currie (2016), 193-5 does not discard imitation of the Gilgamesh episode in Nergal and Ereshkigal, Aqhat and the Song of Ullikummi, on the grounds that Gilgamesh is attested at Ugarit and Hattusa and these scenes share at least two features among 'plaint in heaven' (but we have seen how common this is), 'erotic overtones' (but see the discussion of Elkunirsha and Ashertu below), and 'cosmic threat'. Anat's words at KTU 1.18.i.6-14, however, do not concern cosmic order, as duly noted by Smith and Pitard (n. 74), 344, and Shaushka's lament is not preserved. Concerning the threat repeated almost verbatim at $N \& E$ 316-19, IšD 17-20 and SB Gilg. VI 97-100, the Gilgamesh occurrence is not ideally suited for heading a reception stemma. In $I \check{S} D$, Ishtar, at the Netherworld's gate, menaces to destroy it and thus release the dead, if the gatekeeper does not let her in. The threat is also appropriate to Ereshkigal as Netherworld Queen, but less obviously in context in SB Gilg. (and it is absent from $B B H$ ). I therefore find little justification for the claim of Ponchia and Luukko (n. 69), 60 that the lines in $N \& E$ are a 'literary quotation' from SB Gilg. and $B B H$. With George (n. 3), 474-5, one should probably reserve judgement in the absence of a relative chronology of composition.

${ }^{84}$ CTH 342, Hoffner (n. 69), 90-2, see V. Haas, Die hethitische Literatur. Texte, Stilistik, Motive (Berlin, 2006), 213-16, I. Singer, "The origins of the "Canaanite" Myth of Elkunirša and Ašertu reconsidered', in D. von Groddek and M. Zorman (edd.), Tabularia Hethaeorum (Wiesbaden, 2007), 631-42. Teffeteller (n. 60) offers a comparison with Demodocus' Olympian song in the Odyssey.

${ }^{85}$ Hoffner (n. 69), 90. 16.

${ }^{86}$ H.A. Hoffner Jr., 'The Elkunirša myth reconsidered', Revue hittite et asianique 23 (1965), 5-

${ }^{87}$ Singer (n. 84), 637.

88 H. Otten, 'Ein kanaanäischer Mythus aus Boğazköy', Mitteilungen des Instituts für Orientforschung 1 (1953), 125-50, at 145, Singer (n. 84), 637 n. 46. The ritual connection of the narrative may well have contributed to its translation, cf. Bachvarova (2016), 216. 
Gilgamesh are stylistically much closer to the Hurro-Hittite 'Kumarbi Cycle' than to the Akkadian versions at Hattusa shows that the Babylonian narrative entered a thriving tradition of indigenous poetry. ${ }^{89}$ The scenes involving Shaushka, Ashertu, Anat, and Baal are therefore better viewed within the local (and interconnected) contexts of Hurro-Hittite and West-Semitic literatures, than as inspired by Babylonian models such as Gilgamesh.

Our textual evidence is the product of scribal culture. But the oral dimension accompanying these poetic traditions is increasingly thought to have played a part in cross-cultural literary diffusion in the Near East. Poems were meant to be performed and show unmistakable signs of an aurally-directed style. The HurroHittite texts have been claimed to be 'transitional texts' of orally-derived nature. This would partially explain the type of variations we see in the Hattusan versions of Gilgamesh in Akkadian, Hurrian and Hittite in terms of 'multiformity' or 'mouvance' (similarly to what Paul Zumthor theorized for Medieval poetry, with textual variation partly determined by the existence of an active oral tradition). ${ }^{90}$ Experts in Ugaritic poetry have few doubts about the oral-traditional background of the techniques of repetition and variation, excellent examples of which come to the fore in 'complaint/request scenes'. ${ }^{91}$ Oral transmission alone, incidentally, explains the continuity of literary motifs attested at Ugarit into the Hebrew Bible.

How precisely orality should be accounted for in assessing Sumero-Akkadian narrative poetry is an open question. Assyriologists posit the existence of oral traditions running parallel to the written, but little has been done in the way of a systematic stylistic study of compositional features to see how far they reflect, if not a 'composition-in-performance' oral tradition (which is hardly the case), at least a performance culture. ${ }^{92}$ But it is perhaps not too adventurous to assess the flexible

${ }^{89}$ Cf. Haas (n. 84), 273-6, A. Archi, 'Transmission of recitative literature by the Hittites', Altorientalische Forschungen 34 (2007), 185-203, at 186-8, Bachvarova (2016), 63-72, who notes, at 73, an intriguing parallel between one Hurrian version of Gilgamesh (CTH 341.II.2.i) and Elkunirsha and Ashertu. On the Hurrian tradition as crucially underlying the Hittite Gilgamesh see J. Klinger, 'Die hethitische Rezeption mesopotamischer Literatur und die Überlieferung des Gilgameš-Epos in Hattuša', in D. Prechel (ed.), Motivation und Mechanismen des Kulturkontaktes in der späten Bronzezeit (München, 2005), 103-27.

${ }^{90}$ M. Bachvarova, 'Hurro-Hittite song as a bilingual oral-derived genre', in M. Kapelus and P. Taracha (edd.), Proceedings of the Eighth International Congress of Hittitology (Warsaw, 2014), 77-108; ead. (2016), 35-77; ead. 'Multiformity in the Song of Hedammu: evidence and implications', Altorientalische Forschungen 45 (2018), 1-21. More cautiously Archi (n. 89); id. 'Orality, direct speech, and the Kumarbi cycle', Altorientalische Forschungen 36 (2009), 209-29; G. Beckman, The Hittite Gilgamesh (Atlanta, 2019), 10 n. 48.

91 'Travel to El': KTU 1.1.iii.21-5, 1.2.iii.4-6, 1.4.iv.20-6, 1.17.vi.46-51, with 1.3.v.4-9 significantly varied, cf. Smith and Pitard (n. 74), 339-40; Anat's menaces: 1.3.v.2-3 $\approx 1$.3.v.24-5 $($ Baal Cycle $)=1.18 .1 .11-12$ (Aqhat); El's response: 1.3.v.27-8 $\approx$ 1.18.i.16-17. In chiastic reversal, Asherah's successful plea begins by echoing Anat's belated courteous address (1.4.iv.41-3 = 1.3.v.30-1); Asherah's final reply possibly reverses Anat's previous menacing address to El (1.4.v.3-5 $\approx 1.3$.v.23-5). This illustrates artfulness in 'the flexibility of the use of formulaic passages within similar but fully distinct contexts': Smith and Pitard (n. 74), 351.

92 The status quaestionis has not changed much since M.E. Vogelzang and H.L.J. Vanstiphout (edd.), Mesopotamian Epic Literature: Oral or Aural? (Lampeter, 1992); see Metcalf (n. 3), 143 n. 32, adding M. Civil, 'Reading Gilgameš', Aula Orientalis 17/18 (1999/2000), 179-89, M. Haul, Stele und Legende (Göttingen, 2009), 48-57, C. Wilcke, The Sumerian Poem Enmerkar and En- 
recurrence of stock-lines such as those indicating 'ascent-and-plaint', ${ }^{33}$ or the cosmic menace to release the dead, ${ }^{44}$ as the common performance-directed property of traditionally trained composers.

Though orality is no less of a controversial topic among Homerists, ${ }^{95}$ we have seen that the recurrence of divine complaint/request scenes throughout the early Greek corpus is to be explained in terms of an oral-traditional background. It is more than plausible that early Greek epic singers would learn that an effective way to move the action forward, and to characterize deities and the divine world, was to make them complain to and/or ask something of a hesitating or delaying Zeus. Such scenes were part of the epic repertoire, familiar to audiences, and deployed repeatedly and flexibly in accordance with the purposes of the given context and as a function of the aural reception of poetry. Discussions of literary transmission to Greece should take into account that similar processes are perceptible across the Near East.

The Greek divine complaint/request scene is to be seen as preceding the Homeric poems' shaping, and this points to orality as being crucial for any literary transmission. ${ }^{96}$ In this perspective, let us recall that the 'rejected female who seeks revenge', such as Ishtar in Gilgamesh, Ashertu in Elkunirsha and Ashertu, and (in a rather indirect way) Anat in Aqhat, comes close to the a well-known folk-tale motif including Potiphar's wife and Joseph, Anteia and Bellerophontes, and Phaedra and Hippolytus. ${ }^{97}$ A more exotic example (for the Classicist) stands in the Sanskrit Ramāyaña. This poem's central event is the abduction of Rāma's wife Sìtā by the demonic prince Rāvāṇa, which generates the invasion of Rāvāṇa's city by an army led by Rāma. Why was Sītā abducted? Rāvāṇa's sister Sūrpaṇakhā had propositioned to Rāma and his brother Lakṣmaṇa, but was rejected and humiliated by both and mutilated by Lakșmaña. She went away in terror and confusion, and it is after listening to her complaint that Rāvāna plotted revenge. ${ }^{98}$ Finding our topos at the heart of this traditional orally-derived epic, variously dated between 700 B.C.

suhkeš-ana (New Haven, 2012), P. Delnero, 'Texts and performance: the materiality and function of the Sumerian liturgical corpus', in id. and J. Lauinger (edd.), Texts and Contexts: The Circulation and Transmission of Cuneiform Texts in Social Space (Berlin, 2015), 87-118. K. Hecker, Untersuchungen zur akkadischen Epik (Neukirchen, 1974), the best systematization of Akkadian epic compositional conventions to date, dismissed traditional repetition features as relics of an oral past which should be set aside to recover the poet's originality (especially p. 185).

${ }^{93}$ Texts in George (n. 3), 839, cf. E. Jiménez, Babylonian Disputation Poems (Leiden, 2017), 94-7: the late parodic adaptation is consistent with a perception of the topos as generally pertaining to the epic tradition rather than to individual compositions.

94 Above n. 83.

${ }^{95}$ Most recently Friedrich (n. 30).

${ }^{96}$ Cf. Mondi (n. 7), 150.

${ }^{97}$ Cf. Enzyklopädie des Märchens, s.v. 'Joseph: Der keusche Joseph', Hoffner (n. 69), 90, West (1997), 365, Bachvarova (2016), 34, 424.

${ }^{98}$ Aranyakānda, Sargas 16-40, translation S. Pollock, Rāmāyaṇa, Book Three: The Forest. By Vālmīki (New York, 2006), 125-237. In fact, the complex course of events involves four complaint/request scenes. Śūrpaṇakhā approaches twice another of her brothers, Khara, and only after the latter's definite defeat is Rāvāṇa supplicated by Sūrpaṇakhā. Rāvāṇa then visits the venerable demon Mārīca and asks for his help. When Mārīca tries to dissuade him, Rāvāṇa secures his help with death threats. 
and A.D. 400, but with deep Indo-European roots, should make us wary of positing direct lines of wholesale transmission from the Near East to Greece too readily. ${ }^{99}$ But if the Greek evidence is indeed to be seen in a Near Eastern framework, it supports the idea that connections in that context were fuelled by common narrative structures.

Nevertheless, Homer's Aphrodite scene is not a 'failed seduction and revenge', though the Parisurteil can be connected to this motif. If one accepts that the protagonists' identity should not carry the weight laid upon it hitherto, this Homeric scene is not the best parallel to Ishtar's ascent. The present comparison has therefore focussed on the constellation of typologically similar episodes that cuts across each literary tradition. Divine complaint scenes attest to the broad diffusion of a shared poetic syntax serving commensurate theological discourses. If one considers this to reflect, in part, a cross-fertilisation dynamic, it is reasonable to conclude that this process relied on pre-existing narrative structures and religious conceptions, which facilitated interaction on the level of orality. ${ }^{100}$ None of the Greek scenes appears justifiably to indicate conscious borrowing from any of the preserved Near Eastern sources. One may therefore doubt that the similarities between Greek and Near Eastern complaint scenes go back to Greek hearings of the Gilgamesh Epic, though direct reception is not excluded in principle by this model.

The evidence examined in this article invites us to use analogous categories for studying shared traditional mechanisms. It was through such mechanisms that Near Eastern and Greek poets composed and transmitted their narratives for recitation, and this sharing may have been one common ground that made literary transmission possible. Beyond the present treatment, this may become a basis for distinguishing similarities due to independent developments from what came to be shared as a result of contact and historical diffusion. Detailed comparative analysis of traditional compositional units, moreover, can illuminate meaningful culture- and text-specific differences. It can provide, in sum, a promising framework to better understand the cross-cultural dimensions of ancient epic in the Eastern Mediterranean and Near East.

\footnotetext{
${ }^{99}$ For the Near Eastern 'fertilization' of the Greek Indo-European background see Mondi (n. 7), 147-57, 187-9, López Ruiz (n. 6), 163-4, Metcalf (n. 3), 222-4.

${ }^{100}$ It is not easy to say just how far back in time this should be traced, but the early Iron Age is likely to have been the crucial period. The richest model to date is offered by Bachvarova (2016), especially 199-348, who sees lines of cultural transmission as fostered by elites, especially in ritual contexts. In the case of parallels involving Aphrodite, early Iron Age Cyprus is reasonably thought to be a central node: e.g. Burkert (n. 6, 1984), 95, Cassio (n. 5), Bachvarova (2016), 300-30.
} 